\title{
PEMANFAAAN MEDIA PEMBELAJARAN AUDIO VISUAL FILKARTIKA (FILM KARTUN MATEMATIKA) DENGAN POKOK BAHASAN BANGUN RUANG PADA SISWA KELAS IV SD
}

\author{
${ }^{1}$ Dwi Hariyanti, ${ }^{2}$ Basuki Rachmat, ${ }^{3}$ Murdjito \\ ${ }^{1}$ Mahasiswa Prodi Matematika IKIP PGRI Madiun \\ ${ }^{2}$ Dosen Prodi Matematika IKIP PGRI Madiun \\ ${ }^{3}$ Dosen Prodi Matematika IKIP PGRI Madiun
}

\begin{abstract}
Abstrak. Mata pelajaran matematika merupakan salah satu mata pelajaran yang penting, karena tidak terlepas dari aspek kehidupan sehari-hari. Para siswa sering kali begitu tegang menghadapi pelajaran matematika. Hal ini disebabkan karena siswa sering mendengar bahwa matematika adalah pelajaran yang sulit dan abstrak. Penggunaan media audio visual Filkartika dalam pembelajaran matematika dianggap mampu meningkatkan daya serap siswa terhadap materi pelajaran tersebut. Maka dari itu, peneliti bergagasan untuk menggunakan media audio visual Filkartika sebagai media pembelajaran tontonan edukatif yang menarik dan menyenangkan sehingga membuat siswa menyenangi matematika. Penelitian ini bertujuan untuk mendiskripsikan respon dan hasil belajar siswa dalam pemanfaatan media pembelajaran audio visual Filkartika. Subyek dalam penelitian ini adalah siswa kelas IV SDN 01 Josenan yang dikategorikan menjadi tiga yaitu dua subyek dengan kategori kemampuan tinggi, dua subyek dengan kategori kemampuan sedang, dan dua subyek dengan kategori kemampuan rendah.

Jenis penelitian yang digunakan dalam peelitian ini adalah kualitatif. Metode penelitian yang digunakan yaitu metode observasi, tes dan wawancara. Teknik keabsahan datanya yaitu dengan triangulasi data. Sedangkan teknik analisis datanya terdiri dari empat alur yaitu pengumpulan data, reduksi data, penyajian data dan penarikan kesimpulan serta verifikasi.

Kesimpulan dari hasil penelitian ini adalah $66,67 \%$ siswa menunjukkan respon yang positif terhadap pemanfaatan media Filkartika dan 33,33\% siswa menunjukkan respon negatif. Sedangkan ditinjau dari hasil belajarnya, sebanyak $16,67 \%$ siswa memiliki tingkat penguasaan materi amat baik, sebanyak 33,33\% siswa memiliki tingkat penguasaan materi dengan baik, sebanyak 16,67\% siswa memiliki tingkat penguasaan materi cukup, dan sebanyak 33,33\% siswa memiliki tingkat penguasaan materi amat kurang.
\end{abstract}

Kata Kunci : Media Pembelajaran, Audio Visual, Filkartika, Bangun Ruang

\section{PENDAHULUAN}

Mata Pelajaran matematika merupakan salah satu mata pelajaran yang penting, karena matematika tidak terlepas dari aspek kehidupan sehari hari. Hingga kini mata pelajaran matematika pada tingkat sekolah dasar hingga menengah masih memiliki berbagai masalah atau "momok" diantaranya matematika dianggap mata pelajaran yang sangat sulit dan tidak menarik.

Para siswa sering kali begitu tegang menghadapi pelajaran matematika. Bahkan tidak sedikit dari mereka menjadi hilang kepercayaan saat menghadapi pelajaran yang paling mereka takuti yakni matematika. Hal ini disebabkan karena mereka sering mendengar bahwa matematika adalah pelajaran yang sulit dan abstrak. Selain itu, masih banyak guru yang semakin menambah ketidaksukaan siswa terhadap mata pelajaran matematika. Salah satu diantaranya dikarenakan kreativitas guru yang masih minimal. Sehingga belum dapat membuat siswa tertarik terhadap pelajaran matematika.

Di zaman yang modern ini guru ataupun siswa dituntut untuk dapat mengasah kreativitas mereka agar dapat menghadapi berbagai permasalahan dalam kehidupan sehari-hari. Masih 
jarang sekali guru yang menggunakan media pembelajaran matematika yang menarik minat siswa agar termotivasi untuk mempelajari matematika secara efektif dan menyenangkan. Oleh karena itu, diperlukan suatu media pembelajaran agar kegiatan belajar megajar lebih menarik dan menyenangkan. Sehingga merangsang minat siswa serta mempercepat proses pemahamannya ketika menghadapi suatu permasalahan yang abstrak dan sulit dimengerti menjadi sangat mudah.

Penggunaan media audio-visual dalam pembelajaran matematika dianggap mampu meningkatkan daya serap siswa terhadap materi pembelajaran tersebut. Film kartun merupakan salah satu media audiovisual yang sangat digemari pada usia anak-anak ataupun remaja. Film kartun ini mampu merangsang daya imajinasi anak sehingga memberikan kesan mendalam yang tahan lama. Selain itu, film kartun juga memiliki kemampuan yang besar sekali untuk menarik perhatian, mempengaruhi sikap dan juga tingkah laku anak. Hal ini dikarenakan film kartun biasanya menggunakan karakter yang mudah disukai anak, sehingga kerap kali anak-anak tersebut menjadikan tokoh kartun idolanya sebagai contoh perilaku dalam aktivitas bermainnya. Sayangnya, banyak film kartun yang tidak mendidik disajikan untuk anak-anak sehingga berdampak negatif bagi perilaku anak tersebut. Jika saja fim kartun tersebut bernuansa edukatif, maka perilaku anak-anak pun lebih terdidik.

Berdasarkan permasalahan di atas, maka peneliti bergagasan untuk menggunakan media audio visual Filkartika (Film Kartun Matematika) sebagai media pembelajaran tontonan edukatif yang menarik dan menyenangkan sehingga membuat siswa semakin menyukai matematika.

\section{PEMBAHASAN}

Menurut Wale (2008: 13) matematika adalah ilmu tentang sesuatu yang memiliki pola keteraturan dan urutan yang logis. Menemukan dan mengungkapkan keteraturan atau urutan ini dan kemudian memberikan arti yang merupakan makna dari mengerjakan matematika.

Russel (dalam Hamzah B. Uno, 2007: 129) mendefinisikan bahwa matematika sebagai suatu studi yang dimulai dari pengkajian bagian-bagian yang sangat dikenal menuju arah yang tidak dikenal. Arah yang dikenal tersusun baik (konstruktif) secara bertahap menuju arah yang rumit (kompleks), dari bilangan bulat ke bilangan pecahan, bilangan real ke bilangan kompleks, dari penjumlahan dan perkalian ke diferensial dan integral, dan menuju matematika yang lebih tinggi.

Hamzah B. Uno (2007: 130) berpendapat bahwa hakikat belajar matematika adalah suatu aktivitas mental untuk memahami arti dan hubungan-hubungan serta simbolsimbol, kemudian diterapkannya pada situasi nyata.

Dari berbagai pandangan dan pengertian diatas, dapat disimpulkan bahwa matematika adalah sebagai suatu bidang ilmu yang merupakan alat pikir, berkomunikasi, alat untuk memecahkan berbagai persoalan praktis, yang unsurunsurnya logika dan intuisi, analisis dan konstruksi, generalitas dan individualitas.

Menurut Gagne (dalam Agus Suprijono, 2011: 2) belajar adalah perubahan disposisi atau kemampuan yang dicapai seseorang melalui aktivitas. Perubahan disposisi tersebut bukan diperoleh langsung dari proses pertumbuhan seseorang secara alamiah.

Menurut Witherington (dalam Ngalim Purwanto, 2007: 84) belajar adalah suatu perubahan di dalam 
kepribadian yang menyatakan diri sebagai suatu pola baru daripada reaksi yang berupa kecakapan, sikap, kebiasaan, kepandaian, atau suatu pengertian.

Sedangkan Musfiqon (2012: 2) berpendapat bahwa belajar adalah suatu proses yang kompleks yang terjadi pada setiap orang sepanjang hidupnya, sejak dilahirkan hingga manusia mati.

Dari pendapat-pendapat diatas, maka peneliti dapat menyimpulkan bahwa belajar merupakan suatu kegiatan perubahan kepribadian atau tingkah laku pada seseorang sepanjang hidupnya yang disebabkan oleh terjadinya perubahan pada tingkat pengetahuan, keterampilan maupun sikapnya.

Gagne (dalam R Angkowo dan A Kosasih, 2007: 10) mengartikan media sebagai berbagai jenis komponen dalam lingkungan siswa yang dapat merangsang siswa untuk belajar.

Dari pendapat-pendapat yang telah diungkapkan maka dapat disimpulkan bahwa media pembelajaran adalah segala sesuatu yang dapat menyalurkan pesan, dapat merangsang fikiran, perasaan, perhatian, dan kemauan peserta didik sehingga dapat mendorong terciptanya proses belajar pada diri peserta didik.

Azhar Arsyad (2011: 49) mengatakan Film atau gambar hidup merupakan gambar-gambar dalam frame di mana frame demi frame diproyeksikan melalui lensa proyektor secara mekanis sehingga pada layar terlihat gambar itu hidup. Film bergerak dengan cepat dan bergantian sehingga memberikan visual yang kontinu.

Sedangkan menurut Yudhi Munadi (2008 : 116) Film merupakan alat komunikasi yang sangat membantu proses pembelajaran efektif. Apa yang terpandang oleh mata dan terdengar oleh telinga, lebih cepat dan lebih mudah diingat daripada apa yang hanya dapat dibaca saja atau hanya didengar saja.
Menurut Fatah Syukur NC (2008: 28) Film pendidikan efetif untuk digunakan sebagai alat bantu pengajaran. Film yang diputar di depan siswa harus merupakan bagian integral dari kegiatan pengajaran. Dengan film, dapat melengkapi pengalamanpengalaman dasar, memancing inspirasi baru, menarik perhatian, penyajian lebih baik karena mengandung nilai-nilai rekreasi, dapat memperlihatkan perlakuan obyek yang sebenarnya, sebagai pelengkap catatan, menjelaskan hal-hal abstrak dan lain-lain.

Dari uraian di atas maka dapat disimpulkan bahwa film secara umum merupakan serangkaian gambar yang diambil dari obyek yang bergerak. Gambar obyek tersebut kemudian diproyeksikan ke sebuah layar dan memutarnya dalam kecepatan tertentu sehingga menghasilkan gambar hidup. Film juga berfungsi sebagai alat komunikasi dalam pembelajaran yang efektif karena sifatnya yang lebih mudah diingat.

Menurut Brown (dalam Lukman Arif Film kartun adalah "They present action in continuity as if occures, or as it can be purposely changed to provide some special visual experiences essential to understanding". Adalah sangat istimewa dan mengagumkan hingga dapat menyerupai gambar hidup.

Film kartun dibuat dari gambar-gambar ilustrasi. Gambar ini dibuat satu persatu dengan memperhatikan kesinambungan gerak sehingga ketika diputar rangkaian gerak dalam gambar itu muncul sebagai satu gerakan dalam film.

Dari pengertian film dan kartun yang telah diungkapkan diatas, maka peneliti dapat menyimpulkan bahwa film kartun matematika merupakan suatu media pembelajaran audio visual yang mengkombinasikan matematika dengan sebuah kartun. Objek gambar yang bergerak seolah-olah hidup ini tidak hanya digunakan untuk hiburan saja, namun sangat tepat jika dijadikan 
sebuah media belajar mata pelajaran matematika.

Hal-hal yang bersifat audio-visual biasanya akan mudah diingat oleh anakanak tingkat sekolah dasar karena pada usia sekolah dasar ini yaitu dari usia 612 tahun ialah masanya bagi anak dimana mereka lebih sering menggunakan imajinasi dan khayalan mereka. Dengan mengkombinasikan matematika dengan film kartun yang dianggap sebagai sesuatu yang sangat menarik oleh anak sekolah dasar, bisa di pastikan anak-anak tidak akan pernah malas lagi untuk belajar matematika.

\section{METODE PENELITIAN}

Penelitian ini dilaksanakan pada kelas IV SD Negeri 01 Josenan, Kecamatan Taman Kota Madiun. Subyek dalam penelitian ini adalah siswa kelas IV SDN 01 Josenan yang dikategorikan menjadi tiga yaitu dua subyek dengan kategori kemampuan tinggi, dua subyek dengan kategori kemampuan sedang, dan dua subyek dengan kategori kemampuan rendah.

Sumber data penelitian ini adalah siswa kelas IV, guru, dan dokumen. Teknik pengumpulan data menggunakan metode observasi, tes dan wawancara. Teknik keabsahan datanya yaitu dengan triangulasi data. Sedangkan teknik analisis datanya terdiri dari empat alur yaitu pengumpulan data, reduksi data, penyajian data dan penarikan kesimpulan serta verifikasi.

\section{HASIL PENELITIAN}

Berdasarkan data peneliti dalam tes maupun wawancara maka peneliti akan menuliskan hasil dari analisis data tes dan hasil dari analisis data wawancara sebagai berikut:

\begin{tabular}{|c|c|c|c|c|}
\hline \multirow{2}{*}{ Subyek } & \multicolumn{3}{|c|}{ Analisis Data } & \multirow{2}{*}{ Kategor } \\
\hline & $\begin{array}{c}\text { Nilai } \\
\text { Tes }\end{array}$ & Respon & $\begin{array}{c}\text { Nilai } \\
\text { Penguasaan }\end{array}$ & \\
\hline 1 & 98 & Positif & Amat Baik & Tinggi \\
\hline 2 & 88 & Positif & Baik & Tinggi \\
\hline 3 & 80 & Positif & Baik & Sedang \\
\hline 4 & 78 & Positif & Cukup & Sedang \\
\hline 5 & 36 & Negatif & $\begin{array}{l}\text { Sangat } \\
\text { Kurang }\end{array}$ & Rendah \\
\hline 6 & 25 & Negatif & $\begin{array}{l}\text { Sangat } \\
\text { Kurang }\end{array}$ & Rendah \\
\hline
\end{tabular}

Berdasarkan analisis pemanfaatan media pembelajaran audio visual Filkartika pada pokok bahasan sifat-sifat bangun ruang sesuai dengan tabel, maka peneliti dapat menjelaskan analisis sebagai berikut : a) Pada baris pertama dan kedua merupakan subyek yang memiliki kemampuan tinggi. Dari tabel di atas dapat dilihat bahwa nilai penguasaan setelah pemanfaatan media pembelajaran dengan Filkartika yang dimiliki subyek-1 adalah Amat Baik dan nilai penguasaan yang dimiliki subyek-2 adalah Baik. Sedangkan respon yang diberikan oleh subyek-1 dan subyek-2 terhadap pemanfaatan media pembelajaran Filkartika adalah respon positif. b) Pada baris ketiga dan keempat merupakan subyek yang memiliki kemampuan sedang. Dari tabel di atas dapat dilihat bahwa nilai penguasaan setelah pemanfaatan media pembelajaran dengan Filkartika yang dimiliki subyek-3 adalah Baik dan nilai penguasaan yang dimiliki subyek-4 adalah Cukup. Sedangkan respon yang diberikan oleh subyek-3 dan subyek-4 terhadap pemanfaatan media pembelajaran Filkartika adalah respon positif. c) Pada baris kelima dan keenam merupakan subyek yang memiliki kemampuan rendah. Dari tabel di atas dapat dilihat bahwa nilai penguasaan setelah pemanfaatan media pembelajaran dengan Filkartika yang dimiliki subyek-5 dan subyek-6 adalah 
Amat Kurang. Hal ini diperkuat pula oleh respon yang diberikan oleh subyek5 dan subyek-6 terhadap pemanfaatan media pembelajaran Filkartika adalah respon negatif.

\section{SIMPULAN DAN SARAN}

Dalam penelitian Pemanfaatan Media Pembelajaran Audio Visual "Filkartika" dengan Pokok Bahasan Bangun Ruang pada Siswa Kelas IV SD berdasarkan kajian teori yang didukung oleh hasil penelitian serta mengacu pada tujuan penelitian maka dapat diambil kesimpulan sebagai berikut :

Respon yang diberikan oleh siswa kelas IV SDN 01 Josenan terhadap media pembelajaran audio visual Filkartika ada dua yakni respon positif dan respon negatif. Dari hasil penelitian, yang memberikan respon positif ada 4 siswa dan yang memberikan respon negatif ada 2 siswa. Sehingga dapat disimpulkan bahwa $66,67 \%$ siswa memberikan respon positif dan $33,33 \%$ siswa memberikan respon negatif.

Hasil belajar siswa terhadap media audio visual Filkartika pada siswa kelas IV SDN 01 Josenan cukup bervariasi. Tingkat penguasaan materi sifat-sifat bangun ruang yang dimiliki, antara lain adalah 1 siswa memperoleh nilai ratarata penguasaan yaitu Amat baik, 2 siswa memperoleh nilai rata-rata penguasaan yaitu baik, 1 siswa memperoleh nilai rata-rata penguasaan yaitu cukup, dan 2 siswa memperoleh nilai rata-rata penguasaan yaitu amat kurang. Dapat disimpulkan bahwa 16,67 $\%$ siswa memperoleh tingkat penguasaan Amat Baik, 33,33 \% siswa dengan tingkat penguasaan Baik, 16,67 $\%$ siswa dengan tingkat penguasaan cukup, dan 33,33 \% memiliki tingkat penguasaan Sangat Kurang.

Berdasarkan simpulan dan hasil penelitian ini menunjukkan bahwa pemanfaatan media pembelajaran audio visual Filkartika masih perlu ditingkatkan dan dikembangkan lagi dalam proses pembelajaran, untuk itu peneliti menyarankan :

Kepada Guru

Guru hendaknya lebih kreatif dalam memilih maupun menggunakan media pembelajaran yang bervariatif pada saat pembelajaran matematika agar siswa lebih termotivasi dalam belajar matematika. Salah satunya dapat menggunakan media audio visual Filkartika. Hal ini dapat diperkuat dari hasil rata-rata respon yang diberikan oleh siswa adalah sebesar 66,67\% siswa memberikan respon positif dan hasil belajarnya menunjukkan 66,67 \% memperoleh nilai di atas nilai rata-rata.

Kepada Siswa

Dalam pembelajaran matematika menggunakan media Filkartika, siswa yang sering aktif bertanya memperoleh hasil belajar di atas nilai rata-rata. Oleh karena itu, siswa hendaknya lebih aktif dalam pembelajaran matematika sehingga dapat memperoleh hasil belajar yang lebih baik.

Kepada Peneliti

Pada peneliti lain yang ingin melakukan penelitian yang sejenis tentang penggunaan media pembelajaran audio visual Filkartika dengan pokok bahasan sifat-sifat bangun ruang, hendaknya melakukan observasi yang benar-benar valid. Selain itu, hendaknya dilakukan penelitian lebih lanjut yang bersifat verifikasi dan modifikasi, agar lebih menyakinkan atau memantapkan hasil penelitian ini.

\section{DAFTAR PUSTAKA}

Adi Suryanto, dkk. 2010. Evaluasi Pembelajaran di SD. Jakarta: Universitas Terbuka

Agus Suprijono. 2011. Cooperative Learning. Yogyakarta: Pustaka Pelajar Arief S Sadiman. 2010. Media Pendidikan. Jakarta: PT Raja Grafindo 
Azhar Arsyad. 2011. Media Pembelajaran. Jakarta: PT Raja Grafindo Persada

Darwanto. 2007. Televisi Sebagai Media Pendidikan. Yogyakarta: Pustaka Pelajar

Daryanto. 2011. Media Pembelajaran. Bandung: PT sarana Tutorial Nurani Sejahtera

Fatah Syukur NC. 2008. Teknologi Pendidikan. Semarang: Rasaul Media Group

Hamzah B Uno. 2007. Model Pembelajaran. Jakarta: PT Bumi Aksara Hamzah B Uno dan Nina Lamatenggo. 2010. Teknologi Komunikasi dan Informasi Pembelajaran. Jakarta: PT Bumi aksara

HB Sutopo. 2002. Metodologi Penelitian Kualitatif. Surakarta: Sebelas Maret University Press

Imam Suprayoga dan Tobroni. 2003. Metodologi Penelitian SosialAgama. Bandung: PT Remaja Rosdakarya

Lukman Arif. 2011, 8 Desember. Pengertian Film Kartun. (http://id.shvoong.com/socialsciences/education/2236902pengertian-filmkartun/\#ixzz2FDsFE7c0).

Margono. 2010. Metodologi Penelitian Pendidikan. Jakarta: Rineka Cipta

Moleong, Lexy J. 2007. Metodologi Penelitian Kualitatif. Bandung: PT Remaja Rosdakarya

Musfiqon. 2012. Pengembangan Media dan Sumber Pembelajaran. Jakarta: PT Prestasi Pustakarya
Nana Sudjana. 2007. Teknologi Pengajaran. Bandung: Sinar Baru Algensindo

Ngalim Purwanto. 2007. Psikologi Pendidikan. Bandung: PT Remaja Rosdakarya

R Angkowo dan A Kosasih. 2007. Optimalisasi Media Pembelajaran. Jakarta: PT Grasindo

Sugiyono. 2008. Metode Penelitian Pendidikan. Bandung Alvabeta . 2010. Metode Penelitian

Pendidikan. Bandung Alvabeta

Syaiful Bahri Djamarah dan Azwan Zain. 2010. Strategi Belajar Mengajar. Jakarta : Rineka Cipta

Tanpa Nama. Pemanfaatan Media audio Visual dalam Proses Belajar Mengajar Seni Tari di Sekolah Dasar Negeri 1 Bangirejo Yogyakarta.

(http://eprints.uny.ac.id/9291/3/b ab\%202- \%2007209241033.pdf)

Trianto. 2010. Pengantar Penelitian Pendidikan Bagi Pengembangan Profesi Pendidikan dan Tenaga Kependidikan. Jakarta: Prenada Media Group

Wale, Van De Jhon A. 2008. Matematika Sekolah Dasar dan Menengah. Erlangga

Yudhi Munadi. 2008. Media Pembelajaran. Ciputat: gaung Persada Press

Zainal Arifin. 2011. Evaluasi Media Pembelajaran. Bandung: PT Remaja Rosdakarya 